\title{
Identification and validation of genes involved in cervical tumourigenesis
}

\author{
Thangarajan Rajkumar ${ }^{1 *}$, Kesavan Sabitha ${ }^{1}$, Neelakantan Vijayalakshmi', Sundersingh Shirley ${ }^{2}$, Mayil Vahanan Bose ${ }^{1}$, \\ Gopisetty Gopal', Ganesharaja Selvaluxmy ${ }^{3}$
}

\begin{abstract}
Background: Cervical cancer is the most common cancer among Indian women. This cancer has well defined precancerous stages and evolves over 10-15 years or more. This study was undertaken to identify differentially expressed genes between normal, dysplastic and invasive cervical cancer.

Materials and methods: A total of 28 invasive cervical cancers, 4 CIN3/CIS, 4 CIN1/CIN2 and 5 Normal cervix samples were studied. We have used microarray technique followed by validation of the significant genes by relative quantitation using Taqman Low Density Array Real Time PCR. Immunohistochemistry was used to study the protein expression of MMP3, UBE2C and p16 in normal, dysplasia and cancers of the cervix. The effect of a dominant negative UBE2C on the growth of the SiHa cells was assessed using a MTT assay.
\end{abstract}

Results: Our study, for the first time, has identified 20 genes to be up-regulated and 14 down-regulated in cervical cancers and 5 up-regulated in CIN3. In addition, 26 genes identified by other studies, as to playing a role in cervical cancer, were also confirmed in our study. UBE2C, CCNB1, CCNB2, PLOD2, NUP210, MELK, CDC20 genes were overexpressed in tumours and in CIN3/CIS relative to both Normal and CIN1/CIN2, suggesting that they could have a role to play in the early phase of tumorigenesis. IL8, INDO, ISG15, ISG20, AGRN, DTXL, MMP1, MMP3, CCL18, TOP2A AND STAT1 were found to be upregulated in tumours. Using Immunohistochemistry, we showed overexpression of MMP3, UBE2C and p16 in cancers compared to normal cervical epithelium and varying grades of dysplasia. A dominant negative UBE2C was found to produce growth inhibition in SiHa cells, which over-expresses UBE2C 4 fold more than HEK293 cells.

Conclusions: Several novel genes were found to be differentially expressed in cervical cancer. MMP3, UBE2C and p16 protein overexpression in cervical cancers was confirmed by immunohistochemistry. These will need to be validated further in a larger series of samples. UBE2C could be evaluated further to assess its potential as a therapeutic target in cervical cancer.

\section{Background}

Cervical cancer is the second most common cancer among women worldwide and the most common cancer in Indian women [1]. In most developing countries there are no organized screening programmes, as a result most patients report to tertiary centres in locally advanced stages.

Human papilloma viruses (HPV) have been shown to play a major role in the pathogenesis of cervical cancer, but it alone is not sufficient [2]. Additional events,

\footnotetext{
* Correspondence: drtrajkumar@gmail.com

'Dept. of Molecular Oncology, Cancer Institute (WIA), Chennai, India

Full list of author information is available at the end of the article
}

activation of proto-oncogenes and inactivation of tumour suppressor genes, are required in the induction of cervical cancer.

Cervical cancer goes through a series of pre-malignant stages - Cervical Intraepithelial Neoplasia (CIN) 1, 2 and 3. In general it takes upto about $10-15$ years for the normal cervical epithelial cell to become a malignant one. However, some CIN2 lesions may develop soon after HPV infection, suggesting that there could be alternate pathways involved. CIN1 and 2 have a higher rate of spontaneous reversion compared to CIN3 [3]. The CIN3 then progresses to invasive carcinoma, which can then metastasize to regional lymph nodes and distant organs (e.g. lung).

\section{() Biomed Central}


The advent of microarray based technology has helped study the expression patterns of more than 40,000 genes at a time [4]. Several groups have used microarray based technology to look for differentially expressed genes in the different stages of cervical tumorigenesis $[5,6]$. Few studies have followed up and validated the microarray data in a large number of genes $[7,8]$. The objective of our study was to identify genes differentially expressed between normal cervix, CIN1/CIN2, CIN3/ CIS and invasive cervical cancer, using oligo-microarray technique, validate the genes so identified using Relative quantitation Real Time Polymerase Chain Reaction (RQ-RT-PCR) and detect potential biomarkers for early diagnosis and therapeutic targets.

\section{Methods}

Archival total RNA extracted from punch biopsy samples from patients with cervical cancer, collected in RNA later (Ambion, Austin, USA; Cat no: AM7021) and stored in the tumour bank after an informed consent were used, after obtaining the Institutional Ethical committee's approval for the study. The RNA had been extracted from the biopsy samples using the RNeasy RNA extraction kit (Qiagen, Gmbh, Hilden; Cat no: 74106) as per the manufacturer's instructions.

Twenty eight cervical cancer patients' samples were included in the study. The criteria for inclusion in the study were as follows: 1 . good quality RNA as assessed by Bio-analyser (RIN 6 or above); 2. paired paraffin block having at least $70 \%$ tumour cells; 3 . sufficient quantity of RNA be available; 4 . patient should have completed prescribed radiotherapy and follow-up information till death/last disease free status be available.

In addition, 5 normal cervix tissues from women who underwent hysterectomy for non-malignant conditions or for non-cervical cancer were included. Four CIN1/ CIN2 and 4 CIN3/CIS (one CIN3/CIS was included for RQ-RT-PCR analysis directly) were also included after informed consent. The Normal and CIN samples underwent frozen section to confirm their histopathologic status and the samples were immediately snap frozen in liquid nitrogen. RNA was extracted from the samples using the RNeasy RNA extraction kit, as described above.

\section{HPV Testing}

The quality of the DNA was assessed by amplifying for $\beta$ globin and only then HPV testing was done using GP5+ and GP6+ primers [9]. HPV16 and 18 typing was done using Nested Multiplex Polymerase Chain Reaction (NMPCR) technique [10]. SiHa DNA for HPV16 and HeLa DNA for HPV18 (positive controls) and C33A DNA (negative control) were included in all runs.

\section{Microarray experiment}

$1 \mu \mathrm{g}$ of total RNA from the tumour/CIN/Normal sample and universal RNA (Stratagene; Cat no: 740000-41) were reverse transcribed using Arrayscript at $42^{\circ} \mathrm{C}$ for $2 \mathrm{hrs}$ to obtain cDNA using the Amino Allyl MessageAmp II aRNA amplification kit (Ambion, Austin, USA; Cat no: AM1797). The cDNA was amplified by in-vitro transcription in the presence of T7 RNA polymerase; aRNA thus obtained was purified and quantitated in NanoDrop (NanoDrop Technologies, Wilmington, DE, USA). $20 \mu \mathrm{g}$ of tumour/CIN/Normal aRNA was labelled using NHS ester of Cy5 dye and the control universal aRNA was labelled using NHS ester of Cy3 dye. The Cy3 and Cy5 labelled aRNA was used for hybridization onto the microarray chips from Stanford Functional Genomics Facility (SFGF, Stanford, CA) containing 44,544 spots, for $16 \mathrm{hrs}$ in Lucidea SlidePro hybridization chamber (GE Health Care, Uppsala, Sweden) at $42^{\circ} \mathrm{C}$. After hybridization, slides were washed in $0.1 \times \mathrm{SSC}, 1 \times \mathrm{SSC}$ followed by $0.1 \times$ SSC and dried.

The slides were scanned in ProScanArray (PerkinElmer, Shelton, CT, USA). Griding was done using Scan array Express software package (version -4). The integrated or mean intensity of signal within the spot was calculated. The files were saved as GPR files.

All the raw data files have been submitted to GEO with an assigned GEO accession number - GSE14404.

\section{Microarray dasta analysis}

The Foreground Median intensity for Cy3 and Cy5, Background Median intensity for $\mathrm{Cy} 3$ and $\mathrm{Cy} 5$, spot size data were imported into BRB-ArrayTools software [11] using the Import wizard function. Background correction was not done. Global normalization was used to median centre the log-ratios on each array in order to adjust for differences in labelling intensities of the $\mathrm{Cy} 3$ and Cy5 dyes. The data was analysed using the Class comparison and Class prediction modules in the BRBArray Tools software. In addition, Lowess normalization was also done separately and the data analysed using the modules mentioned above. The normalized Log ratios were also imported into Significance Analysis of Microarray (SAM) [12] software and analysed.

\section{Class Comparison in BRB-Array Tools}

We identified genes that were differentially expressed among the four classes (Normal, CIN1/2, CIN3/CIS, Cancer) using a random-variance t-test. The randomvariance t-test is an improvement over the standard separate $\mathrm{t}$-test as it permits sharing information among genes about within-class variation without assuming that all genes have the same variance [13]. Genes were considered statistically significant if their $\mathrm{p}$ value was $<0.01$. In addition a two fold difference was required 
between the Cancer and Normal, CIN3/CIS and Normal, CIN1/2 and Normal. The same was repeated with the Lowess normalized data using the same criteria.

\section{Class prediction in BRB-Array Tools}

We developed models for utilizing gene expression profile to predict the class of future samples based on the Diagonal Linear Discriminant Analysis and Nearest Neighbour Classification [11]. The models incorporated genes that were differentially expressed among genes at the 0.01 significance level as assessed by the random variance t-test [13]. We estimated the prediction error of each model using leave-one-out cross-validation (LOOCV) as described [14]. Leave-one-out cross-validation method was used to compute mis-classification rate. From the list, genes were sorted further based on 2 fold difference between Cancer versus CIN1/2 \& Normal, CIN3/CIS versus CIN1/2 \& Normal, and CIN1/2 versus Normal. The same was repeated with the Lowess normalized data using a significance value of 0.01 .

\section{SAM Analysis}

The normalized log ratios of all the samples were imported into SAM software and analysed. A Multiclass analysis with 100 permutations was done. A delta value of 0.96 and a fold difference of 2 was used to identify the genes differentially expressed.

\section{Quantitative Real time PCR}

High Capacity Reverse Transcription kit (Applied Biosystems, Foster City, CA; Cat no: 4368814) was used to reverse transcribe $2 \mu \mathrm{g}$ of total RNA from the 38 samples in a $20 \mu \mathrm{l}$ reaction volume. In 3 samples, due to the limiting amount of RNA, $0.75 \mu \mathrm{g}$ was used for the cDNA synthesis.

These cDNA samples were used for real time PCR amplification assays using $\operatorname{TaqMan}^{\circledR}$ arrays formerly TaqMan ${ }^{\circledR}$ Low density arrays (TLDA) (Applied Biosystems, Foster City, CA; Cat no: 4342261). The fluorogenic, FAM labelled probes and the sequence specific primers for the list of genes with endogenous control $18 \mathrm{~S}$ rRNA were obtained as inventoried assays and incorporated into the TaqMan ${ }^{\circledR}$ array format. Quadruplicate $(\mathrm{n}=38)$ and duplicate $(\mathrm{n}=3$; with limiting amount of RNA for cDNA synthesis) cDNA template samples were amplified and analysed on the ABI Prism 7900HT sequence detection system (Applied Biosystems, Foster City, CA).

The reaction set up, briefly, consisted of $1.44 \mu \mathrm{g}$ of cDNA template made up to $400 \mu \mathrm{l}$ with deionised water and equal amounts of TaqMan ${ }^{\circledR}$ Universal PCR Master Mix (Applied Biosystems, Foster City, CA; Cat no: 4304437). $100 \mu \mathrm{l}$ was loaded into each of the 8 ports of the array ( 2 ports comprise of one sample replicate on the array). Thus, the samples run as duplicates were only loaded into 4 ports of the array. Thermal cycling conditions included a $50^{\circ} \mathrm{C}$ step for 2 minutes, denaturation for $10 \mathrm{~min}$ at $94^{\circ} \mathrm{C}$ followed by 40 cycles consisting of 2 steps: $97^{\circ} \mathrm{C}$ for 30 seconds and $59.7^{\circ} \mathrm{C}$ for 1 minute for annealing and extension.

The raw data from the Prism 7900HT sequence detection system was imported into the Real-Time StatMiner $^{\mathrm{TM}}$ software for statistical analysis of the data. Among the endogenous reference genes included on the array (18S ribosomal gene; UBC, $\beta 2$ microglobulin), UBC and $\beta 2$ microglobulin were chosen after visualizing the global Ct value distribution, for normalizing the data (Supplementary figure 1). The TLDA assays were run at LabIndia Instruments Pvt Ltd laboratories at Gurgaon, New Delhi.

\section{Immunohistochemistry (IHC)}

IHC was done for MMP3 protein expression in 5 Normal cervical tissue, 30 dysplasias of varying grade (CIN1 - 11; CIN2 - 8; CIN3/CIS - 11) and 27 invasive cervical cancers. A 3 layered ABC technique was used as described previously [15]. MMP3, monoclonal antibody (Sigma Aldrich, India; cat no: M6552) was used at a dilution of 1:75 and with wet antigen retrieval method. Positive control (section from a pancreatic cancer) and negative control (omission of primary antibody) were included in each run. The slides were scored by SS and TR independently and where discordant, jointly. The scoring was based on percentage of tumour cells immunoreactive (negative $-0 ;<25 \%=1 ; 25-50 \%-2 ; 51$ $75 \%-3 ;>75 \%-4$ ), intensity of immunoreactivity (negative $-0 ;+-1 ;++-2 ;+++-3$ ) and the compartment stained (cytoplasmic, nuclear or stromal). The scores obtained were added and the threshold was set at above the scores seen in the Normal cervical tissue (maximum score seen in Normal cervical tissue was 8). Hence tissues with a score of 9 or above were considered to overexpress MMP3.

p16 IHC was done as described previously [16] on 5 normal cervical tissue, 31 dysplasias of varying grades (CIN1 - 12; CIN2 - 8; CIN3/CIS - 11) and 29 tumours. Slides were scored as reported previously [16].

UBE2C IHC was done as above using wet autoclaving with a hold time of 5 minutes. Rabbit UBE2C polyclonal antibody (Millipore, USA - catalogue no: AB3861) was used at 1 in 100 dilution. The scoring was done similar to the scoring of MMP3 staining, with the maximum score seen in normal cervical tissue being 6 . Hence a score of 7 or above was considered to be overexpression. UBE2C in cervical cancer cell lines

Taqman Real time PCR was done for UBE2C levels in SiHa, C33A, HeLa, ME180, BU25K and HEK293 (Human embryonic kidney cells) cell lines. GAPDH was used to normalize the data. 
Dominant negative UBE2C, in which Cysteine 114 is replaced by Serine, leading to loss of catalytic activity [17] was introduced into $\mathrm{SiHa}$ cells, using Fugene 6 Transfection Reagent (Roche Applied Science) according to the manufacturer's instructions using a 3:2 Fugene/ DNA ratio. The effect on growth was assessed using the MTS assay (Promega) in the SiHa wild type (WT), in $\mathrm{SiHa}$ with pcDNA vector alone (SiHa pcDNA) and in $\mathrm{SiHa}$ with dominant negative UBE2C (SiHa DNUBE2C).

\section{Statistical analysis}

Comparison between group means was assessed using a one-way ANOVA and multiple-comparison correction by Holm-Sidak method using Sigmaplot version 11.0. Fisher's exact test ( 2 tailed) was used to assess significance of IHC immuno-reactivity between cancer and dysplasias.

\section{Results}

The stage distribution of the invasive cancer cases was as follows: IB - 2, IIA - 4, IIB - 18 and IIIB - 4. Twenty seven of the tumours were Squamous cell carcinomas (18 Large cell non-keratinizing, 5 large cell keratinizing and 4 unspecified) and one was a poorly differentiated carcinoma. Eighteen were HPV16 positive, 6 were HPV18 positive and 4 were HPV16 and 18 subtype negative (but HPV positive). All the Normals were HPV negative while one CIN1/2 and all the CIN3/CIS were HPV16 positive.

Using different methods, as described above, genes that were found to be differentially expressed between the four classes (Normal, CIN1/2, CIN3/CIS and Cancer) were identified. We did not use a Training set and a Test set for the Class Prediction model but used LOOCV for cross-validation and obtain the misclassification error. The list of genes significant by different methods of microarray analysis is given in the Additional File 1 (AF1).

Sixty nine genes were selected for further validation by RQ-PCR using the Taqman Low Density Array card (TLDA) format (Additional File 2). These 69 genes formed part of the 95 genes selected for analysis using the TLDA format. The additional genes were those which had been found to be differentially expressed between the responders and non-responders to radiotherapy only treatment. Apart from the mandatory endogenous $18 \mathrm{~S}$ rRNA included in the TLDA cards, based on the microarray data, UBC and $\beta 2$ microglobulin, were included as additional endogenous reference genes.

Two of the samples CXL19-hov160 and CXM024hov210 which had worked in microarray did not amplify satisfactorily in the RQ-TLDA assay and had to be removed from further analysis. In addition, RPS3A gene did not amplify in any of the samples.

The RQ values after calibrating with the Normal samples (Mean) for all the 94 genes showed 8 additional genes to be overexpressed; 4 (ASB16, CCL18, FST, THOC6) in Cancers, 1 (KLK9) in CIN3/CIS and 3 (RASSF6, TMEM123 and GLB1L3) in CIN1/2 samples. These 8 genes had initially been chosen for validation of the differentially expressed genes between responders and non-responders to radiotherapy. After excluding the genes which did not amplify, we now had 76 genes for further analysis.

Of the 31 genes which had been selected based on a greater than 2 fold difference between cancer versus CIN1/2 \& Normal, 28 were concordant between the microarray data and the RQ-RT-PCR (Concordant rate of $90 \%$ ). Three of four genes selected based on higher level of expression in Normals compared with all other classes showed concordance between the different methods of analysis. In the case of CIN $1 / 2$, concordance was seen in $6 / 7$ genes $(86 \%)$. However, with CIN3, this dropped to $41 \%(11 / 27)$. In four additional genes, there was a two fold greater difference between CIN3/CIS and Normal but not with CIN1/2. The overall concordance rate between the microarray data and the RQ-RT-PCR was $70 \%(48 / 69)$.

The list of genes validated and found to have a greater than 2 fold difference compared to the Normal, in the 3 different classes (Cancer, CIN3/CIS and CIN1/2) is given in Table 1 . Figure 1 provides the fold change relative to Normal for these genes.

The genes were grouped on the basis of whether or not they were known to be involved in cervical tumorigenesis (Tables 2 and 3). Gene Ontology mapping was done using Babelomics software [18], which showed an over-representation of genes involved in cell cycle, cell division, catabolic process and multi-cellular organismal metabolic process. The genes identified to be differentially expressed were then analysed for specific pathways of relevance by manual curetting of data from published literature and online databases. The genes were grouped under the following categories: 1 . Cell cycle regulatory genes $(n=13) ; 2$. Interferon induced genes $(n=5) ; 3$. Ubiquitin pathway $(\mathrm{n}=5)$; 4. Myc Pathway [19] $(\mathrm{n}=$ 12); 5. HPV-E6/E7 related genes [20] $(n=14) ; 6$. RNA targeting genes $(\mathrm{n}=3)$ (details are given in Additional File 3 ). In addition, 40 genes in our list were found to be potentially regulated by p53 family of genes [21] (Additional File 4). Using GeneGo's Metacore software (Trial version) (url: http://www.genego.com), the relationship of our validated genes with known Transcription factors was analyzed. Based on this and from the manually curetted information, we then attempted to 
Table 1 Rq Values For The Genes Relative To Normal

\begin{tabular}{|c|c|c|c|c|c|}
\hline & TUMOR & CIN3 & CIN1 & $\begin{array}{r}p \\
\text { VALUE }\end{array}$ & $\begin{array}{r}\text { ADJUSTED } \\
\text { p VALUE }\end{array}$ \\
\hline \multicolumn{6}{|l|}{ CANCER } \\
\hline AGRN & 4.43991 & 0.87936 & 1.30918 & $1.95 \mathrm{E}-06$ & $1.22 \mathrm{E}-05$ \\
\hline APOBEC3B & 28.7531 & 5.01379 & 8.85884 & 0.00203 & 0.00465097 \\
\hline ASB16 & 11.8884 & 2.29963 & 1.66354 & 0.01969 & 0.033056418 \\
\hline $\begin{array}{l}\text { C20orf42/ } \\
\text { FERMT1 }\end{array}$ & 4.39903 & 2.94499 & 5.01419 & $3.16 \mathrm{E}-05$ & 0.000123866 \\
\hline$\overline{C C L 18}$ & 7.20321 & 1.62004 & 0.0723 & 0.00717 & 0.013221849 \\
\hline $\mathrm{CDC} 20$ & 19.7377 & 13.8732 & 3.55849 & $2.98 \mathrm{E}-12$ & $2.80 \mathrm{E}-10$ \\
\hline CDC25B & 3.2086 & 1.52287 & 1.4008 & $6.66 \mathrm{E}-05$ & 0.000231975 \\
\hline $\mathrm{CDH} 3$ & 29.0774 & 13.1587 & 10.9346 & 4.79E-08 & $6.44 \mathrm{E}-07$ \\
\hline CDKN2A & 274.282 & 731.037 & 21.5102 & 2.75E-09 & $6.46 \mathrm{E}-08$ \\
\hline CKS1B & 2.13404 & 1.45612 & 0.69024 & 0.43779 & 0.587807354 \\
\hline CKS2 & 8.23126 & 6.96362 & 1.77975 & $2.75 \mathrm{E}-10$ & $1.29 \mathrm{E}-08$ \\
\hline COL7A1 & 7.1098 & 2.76264 & 5.36018 & $2.29 \mathrm{E}-06$ & $1.34 \mathrm{E}-05$ \\
\hline DTX3L & 2.02309 & 1.16971 & 1.156 & 0.00341 & 0.006842128 \\
\hline FST & 3.82365 & 0.71799 & 1.70232 & 0.04615 & 0.06996509 \\
\hline IGF2BP2 & 2.47182 & 0.45821 & 2.32119 & 0.13561 & 63734 \\
\hline IL8 & 5.09435 & 0.86174 & 0.12926 & 0.00384 & 0.007519964 \\
\hline INDO & 9.6009 & 1.25824 & 0.94788 & 0.00063 & 0.001856627 \\
\hline ISG15 & 13.9329 & 2.06597 & 2.16239 & $3.44 \mathrm{E}-07$ & $3.23 \mathrm{E}-06$ \\
\hline ISG20 & 2.11654 & 0.49943 & 0.3666 & 0.05737 & 0.080570517 \\
\hline KRT17 & 20.0558 & 3.92122 & 1.04329 & $1.42 \mathrm{E}-08$ & $2.50 \mathrm{E}-07$ \\
\hline LAMB3 & 13.6 & 2.4397 & 4.96423 & 5.70E-06 & $82 \mathrm{E}-05$ \\
\hline MCM4 & 3.85854 & 1.34001 & 1.07006 & 0.0004 & 0.001222519 \\
\hline MCM6 & 2.38446 & 1.48791 & 0.87143 & 0.00451 & 0.00865803 \\
\hline MELK & 6.63844 & 5.96901 & 2.12471 & $1.75 \mathrm{E}-06$ & $1.17 \mathrm{E}-05$ \\
\hline$\overline{M M P 1}$ & 125.944 & 2.52253 & 0.1402 & $4.30 \mathrm{E}-07$ & $3.67 E-06$ \\
\hline MMP3 & 40.0729 & 0.30275 & 0.03493 & 4.44E-05 & 0.000166947 \\
\hline NUP210 & 4.14316 & 3.45836 & 1.34658 & 0.00106 & 0.002782383 \\
\hline PLOD2 & 2.41806 & 2.21483 & 1.11276 & 0.00709 & 0.013221849 \\
\hline SLC16A1 & 6.71744 & 2.80011 & 3.82016 & 0.00092 & 0.002541873 \\
\hline SLC2A1 & 5.69119 & 3.34455 & 2.93698 & 0.00079 & 0.002242462 \\
\hline SMC4 & 3.93197 & 3.28125 & 1.65161 & $1.72 \mathrm{E}-05$ & $7.68 \mathrm{E}-05$ \\
\hline STAT1 & 9.1538 & 2.15413 & 3.16578 & 9.84E-05 & 0.000330443 \\
\hline THOC6 & 2.73991 & 1.63077 & 1.93361 & 0.08808 & 0.197141325 \\
\hline TK1 & 13.4525 & 7.11209 & 2.42871 & 4.91E-10 & $1.54 \mathrm{E}-08$ \\
\hline TOP2A & 2.72523 & 1.82496 & 1.08463 & 0.00164 & 0.003959245 \\
\hline UBE2C & 14.054 & 12.1512 & 4.10121 & $3.51 \mathrm{E}-06$ & $1.83 \mathrm{E}-05$ \\
\hline C20orf114 & 0.00068 & 0.01085 & 0.1082 & 0.0002 & 0.000644363 \\
\hline FCGBP & 0.01637 & 0.11346 & 0.23912 & $4.98 \mathrm{E}-05$ & 0.00017995 \\
\hline RGS5 & 0.0692 & 0.40561 & 0.58543 & 9.63E-07 & $6.96 \mathrm{E}-06$ \\
\hline$R P L 10 A$ & 0.42083 & 0.89019 & 1.54046 & 0.01077 & 0.019108208 \\
\hline$R P L 13 A$ & 0.39404 & 0.62725 & 0.96561 & 0.00199 & 0.00465097 \\
\hline SPINK5 & 0.00677 & 0.0817 & 1.38502 & 9.33E-06 & 4.39E-05 \\
\hline TFF3 & 0.00108 & 0.02275 & 0.23349 & $3.40 \mathrm{E}-07$ & $3.23 \mathrm{E}-06$ \\
\hline TPD52L1 & 0.26451 & 1.71067 & 1.8713 & 0.00218 & 0.004873472 \\
\hline
\end{tabular}

Table 1 Rq Values For The Genes Relative To Normal (Continued)

\begin{tabular}{|c|c|c|c|c|c|}
\hline CIN3 & & & & & \\
\hline CALML5 & 0.51194 & 10.2307 & 5.18399 & 0.00709 & 0.05123751 \\
\hline CCNB1 & 10.6825 & 10.44 & 2.79343 & 0.0175 & 0.090329125 \\
\hline CCNB2 & 6.74715 & 7.52496 & 2.54768 & 0.00064 & 0.008554526 \\
\hline EBP & 2.05888 & 5.0445 & 3.49571 & 0.00027 & 0.008554526 \\
\hline FLJ44635 & 1.40964 & 6.98147 & 3.89307 & 0.22913 & 0.365061765 \\
\hline KLK9 & 11.7606 & 30.8271 & 26.324 & 0.01049 & 0.065711523 \\
\hline NUSAP1 & 1.92037 & 6.57218 & 1.75057 & 0.00533 & 0.049372841 \\
\hline PCNA & 1.76308 & 2.64579 & 0.92838 & 0.01586 & 29125 \\
\hline CIN1 & & & & & \\
\hline B4GALT1 & 1.29547 & 0.63469 & 2.21031 & 0.05915 & 0.166469075 \\
\hline CAPNS2 & 0.32306 & 1.98671 & 2.3676 & 0.01723 & 0.095298509 \\
\hline CD36 & 0.71359 & 10.6158 & 14.142 & 0.00889 & 0.052209988 \\
\hline CRNN & 0.00053 & 0.40085 & 12.1177 & 0.00104 & 0.027439506 \\
\hline CSTB & 0.17911 & 0884 & 4.5624 & 0.00263 & 0.029029697 \\
\hline CXCL14 & 0.09773 & 1.49396 & 11.7379 & 0.07384 & 0.182664861 \\
\hline DAPL1 & 0.03534 & 1.35468 & 6.09254 & 0.00067 & 0.027439506 \\
\hline$D B I$ & 0.40666 & 2.15767 & 3.98554 & 0.00469 & 0.031486868 \\
\hline DYNLL1 & 5.20441 & 4.20119 & 6.97185 & 0.07896 & 0.185551839 \\
\hline FBLN1 & 0.15796 & 0.34282 & 2.85624 & 0.05894 & 0.166469075 \\
\hline$\overline{G J A 1}$ & 0.16263 & 0.60199 & 3.58862 & 0.0017 & 0.029029697 \\
\hline GLB1L3 & 0.11823 & 0.47805 & 5.23721 & 0.04676 & 0.16283811 \\
\hline HEBP2 & 0.82928 & 1.50603 & 2.15449 & 0.03338 & 0.144693437 \\
\hline HOPX & 0.04259 & 0.57251 & 2.37465 & 0.07856 & 0.185551839 \\
\hline KRT10 & 0.50079 & 7.42996 & 107.277 & 0.00309 & 0.029029697 \\
\hline KRTDAP & 0.00637 & 0.61177 & 10.8535 & 0.00431 & 0.031486868 \\
\hline MAFB & 1.18718 & 2.08998 & 4.15406 & 0.0029 & 0.029029697 \\
\hline RASSF6 & 2.55599 & 3.073 & 8.63768 & 0.00189 & 0.029029697 \\
\hline SLURP1 & 0.00845 & 0.56737 & 7.04202 & 0.00117 & 0.027439506 \\
\hline MEM123 & 2.77691 & 1.00492 & 19.4085 & 0.03995 & 0.150195313 \\
\hline
\end{tabular}

\section{GENES WITH LESS THAN TWO FOLD DIFFERENCE IN THE 3}

\section{CLASSES}

\begin{tabular}{lrrrrr}
\hline PARP14 & 1.61309 & 0.75545 & 0.6995 & 0.04808 & 0.071743665 \\
\hline RPS8 & 0.75787 & 0.87528 & 0.97209 & 0.59992 & 0.65977976 \\
\hline RPL9 & 1.34116 & 0.44416 & 0.59991 & 0.41918 & 0.49253415 \\
\hline TIMM8B & 0.82901 & 1.51431 & 1.92649 & 0.55825 & 0.628406378
\end{tabular}

Gene symbols in bold italics indicate those which were not concordant between microarray and RQ-RT-PCR analysis.

construct relationship chart (Figure 2) providing information on the gene interactions.

Using IHC, we studied the protein expression for MMP3 in 5 normal cervical tissues, 30 dysplasias of varying grades and 27 invasive cancers. Using a semiquantitative scoring system and a cut-off threshold set based on the normal cervical tissue staining, 6/30 dysplasias and 11/27 invasive cancers were found to overexpress MMP3 protein (Figure 3A). Among the patients 


\section{RQ VALUES FOR SIGNIFICANT GENES}

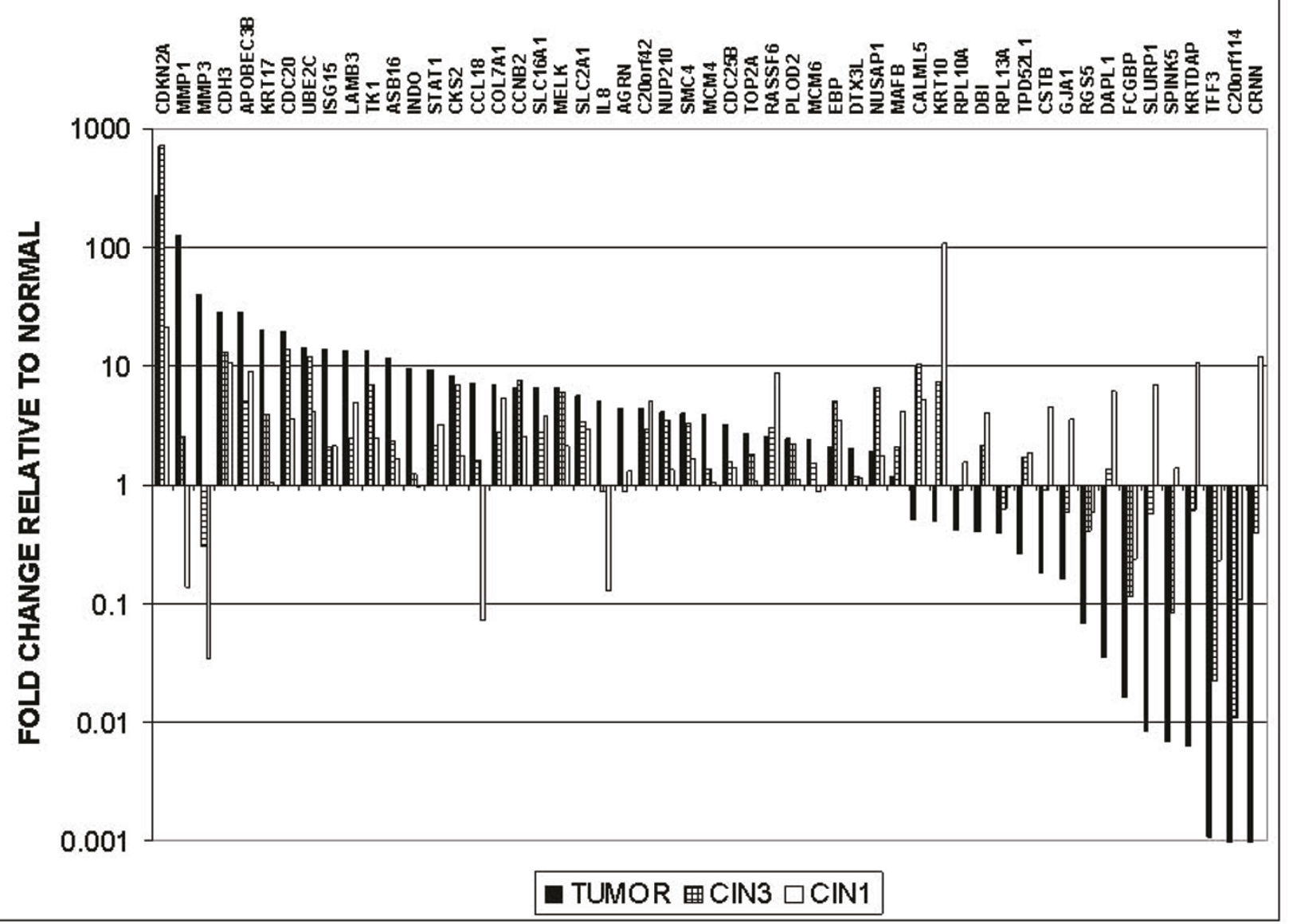

Figure 1 Relative quantitation levels of significant genes

Table 2 Genes Identified as Up or Down-Regulated In Cervical Cancers For The First Time

\begin{tabular}{|c|c|c|c|}
\hline $\begin{array}{l}\text { S. } \\
\text { No: }\end{array}$ & $\begin{array}{l}\text { GENE } \\
\text { SYMBOL }\end{array}$ & FUNCTION & CANCERS WHEREIN UP-REGULATION REPORTED \\
\hline 1 & AGRN & Basement membrane component & Hepatocellular carcinoma (HCC) [27], Synovial sarcoma [28] \\
\hline 2 & CCL18 & Attracts lymphocytes towards dendritic cell & Gastric cancer [29] \\
\hline 3 & CKS1B & Cell cycle & Breast cancer [30] etc. \\
\hline 4 & COL7A1 & Epithelial basement membrane organization & Oesophageal cancer [31] \\
\hline 5 & DNYLL1/DLC1 & Inhibits neuronal nitric oxide synthase & Breast cancer [32] \\
\hline 6 & FERMT1 & Cell adhesion; TGF- $\beta$ signalling & Lung and colon cancer [33] \\
\hline 7 & FST & $\begin{array}{l}\text { Activin antagonist; inhibits synthesis and secretion } \\
\text { of FSH }\end{array}$ & Wilm's tumour, Basal cell carcinoma [34] \\
\hline 8 & IGF2BP2 & Regulate translation of target mRNA & Testicular cancer [35], HCC [36] \\
\hline 9 & IL8 & Inflammatory cytokine & Several cancers; HR-HPV+VIN [37] \\
\hline 10 & KLK9 & Serine protease & Bladder cancer [38], breast cancer [39] \\
\hline 11 & MELK & Leucine zipper kinase & Colo-rectal cancer, lung cancer [40], brain cancer [41] \\
\hline 12 & PLOD2 & Lysyl hydroxylase & Glioblastoma [42] \\
\hline 13 & RASSF6 & Tumour suppressor & Low levels detected in HeLa cell line [43] \\
\hline 14 & SLC16A1 & Monocarboxylate transporter & Neuroblastoma [44] \\
\hline
\end{tabular}


Table 2 Genes Identified as Up or Down-Regulated In Cervical Cancers For The First Time (Continued)

\begin{tabular}{|c|c|c|c|}
\hline 15 & SMC4 & Chromosome condensation; DNA repair & Breast cancer [45] \\
\hline 16 & APOBEC3B & RNA editing enzyme & None to date \\
\hline 17 & ASB16 & Ubiquitin pathway & None to date \\
\hline 18 & NUP210 & Nuclear pore complex & None to date \\
\hline 19 & THOC6 & Splicesome associated protein & None to date \\
\hline \multirow[t]{2}{*}{20} & TMEM123 & Induces Pro-oncosis type cell death & None to date \\
\hline & CIN3 & & \\
\hline 1 & CCNB2 & Cell cycle & Lung [46], pituitary tumours [47] \\
\hline 2 & EBP & ER Protein & ALK+ Anaplastic large cell lymphoma [48] \\
\hline 3 & NUSAP1 & Microtubule associated protein & Melanoma [49] \\
\hline 4 & CALML5 & Calcium binding protein & Psoriasis [50] \\
\hline \multirow[t]{2}{*}{5} & FLJ44635 & TPT1-like protein & None to date \\
\hline & & & CANCERS WHEREIN DOWN-REGULATION REPORTED \\
\hline 1 & C20ORF114 & Innate immunity & Nasopharyngeal cancer [51] \\
\hline 2 & CRNN & Tumour suppressor & Tongue cancer [52] \\
\hline 3 & CSTB & Thiol proteinase inhibitor; anti-metastatic & Laryngeal cancer [53] \\
\hline 4 & $\mathrm{DBI}$ & Intracellular carrier for Acyl-COA esters & Overexpressed in Brain tumours [54] \\
\hline 5 & FCGBP & Maintenance of mucosal surface & Prostate [55] \\
\hline 6 & HOPX & Tumour suppressor & Choriocarcinoma [56] and lung cancer [57] \\
\hline 7 & SLURP1 & Anti-tumour; anti-angiogenic & Hypopharyngeal cancer; Can induce apoptosis in Kaposi's sarcoma [58] \\
\hline 8 & SPINK5 & Serine protease inhibitor & Tongue cancer [59] \\
\hline 9 & TFF3 & Protect mucosa & $\begin{array}{l}\text { Down-regulated in highly invasive colon cancers [60] and in thyroid } \\
\text { cancers [61] }\end{array}$ \\
\hline 10 & CAPNS2 & Thiol protease & None to date \\
\hline 11 & DAPL1 & Epithelial differentiation & None to date \\
\hline 12 & GLB1L3 & Galactosidase beta1 like & None to date \\
\hline 13 & HEBP2 & Heme binding protein & None to date \\
\hline 14 & KRTDAP & Keratinocyte differentiation & None to date \\
\hline
\end{tabular}

Table 3 Genes Known To Be Up or Down-Regulated In Cervical Cancers Found Also In Our Study UP-REGULATED

\begin{tabular}{|c|c|c|c|}
\hline $\begin{array}{l}\text { S } \\
\text { NO: }\end{array}$ & $\begin{array}{l}\text { GENE } \\
\text { SYMBOL }\end{array}$ & FUNCTION & REFERENCES \\
\hline 1 & CCNB1 & Cell cycle & Overexpressed in cervical cancers [62] \\
\hline 2 & CDC20 & Cell cycle & HR-HPV E2 interaction [63] \\
\hline 3 & CDC25B & Cell cycle & FOXM1 increases Cyclin B1, CDC25B, Cyclin D1 in cervical cancers [64] \\
\hline 4 & $\mathrm{CDH} 3$ & Cell adhesion & P-Cadherin predominant cadherin in high grade cervical dysplasia [65] \\
\hline 5 & CDKN2A & Cell cycle & Overexpressed in high grade dysplasia and invasive cancers [66] \\
\hline 6 & CKS2 & Cell cycle & Overexpressed in cervical cancer [67] \\
\hline 7 & DTX3L & Ubiquitin pathway & Overexpressed in cervical cancer [68] \\
\hline 8 & INDO/IDO1 & Immuno-suppression & Role in inducing immunosuppression in the tumour milleu [69] \\
\hline 9 & ISG15/G1P2 & Ubiquitin like protein & Over-expressed in invasive cancer [70] \\
\hline 10 & ISG20 & Exonuclease with higher affinity for RNA & Up-regulated by HPV E6 [71] \\
\hline$\overline{11}$ & KRT17 & $\begin{array}{l}\text { Intermediate filament; marker for } \\
\text { epithelial "stem cells" }\end{array}$ & Overexpressed in cervical cancer [72] \\
\hline 12 & LAMB3 & Basement membrane protein & HR-HPV-E6 inhibits miR-218 which regulates LAMB3 [73] \\
\hline$\overline{13}$ & MCM4 & Cell cycle & Widely expressed in cervical cancers [74] \\
\hline 14 & MCM6 & Cell cycle & Over-expressed in cancer [75] \\
\hline
\end{tabular}


Table 3 Genes Known To Be Up or Down-Regulated In Cervical Cancers Found Also In Our Study (Continued)

\begin{tabular}{|c|c|c|c|}
\hline 15 & MMP1 & Breakdown of extracellular matrix & Overexpressed in cervical cancers [76] \\
\hline 16 & MMP3 & Breakdown of extracellular matrix & $\begin{array}{l}\text { Metastatic lymphnodes in cervical cancer harbour MMP3 positive tumour cells [77]; } \\
\text { Increased in stroma in cancers [78] }\end{array}$ \\
\hline 17 & SLC2A1 & Glucose transporter & Expressed in CIN and invasive cervical cancers [79] \\
\hline 18 & STAT1 & Transcription activator & Overexpressed in cervical cancers [80] \\
\hline 19 & TK1 & Thymidine kinase & Up-regulated in invasive cancers [81] \\
\hline 20 & TOP2A & Topoisomerase & Overexpressed in cervical cancers [82] \\
\hline \multirow[t]{2}{*}{21} & UBE2C & Ubiquitin pathway & Overexpressed in cervical cancer [76] \\
\hline & CIN3 & & \\
\hline 1 & PCNA & Cell cycle & Major up-regulation of PCNA upon progression to CIN3 [83] \\
\hline \multicolumn{4}{|c|}{ DOWN-REGULATED } \\
\hline 1 & FBLN1 & Cell adhesion; tumour suppressor & E6 binds to Fibulin1 and modulates its activity [84] \\
\hline 2 & CD36 & Cell adhesion & CD36 down-regulated in high grade dysplasias and cancer [85] \\
\hline 3 & CXCL14 & Immunoregulatory cytokine & Down-regulated in cervical and head and neck cancers [86] \\
\hline 4 & GJA1 & Gap junction & Down-regulated in CIN3 and invasive cancers [87] \\
\hline 5 & KRT10 & Intermediate filament & Down-regulated in invasive cancer [72] \\
\hline
\end{tabular}

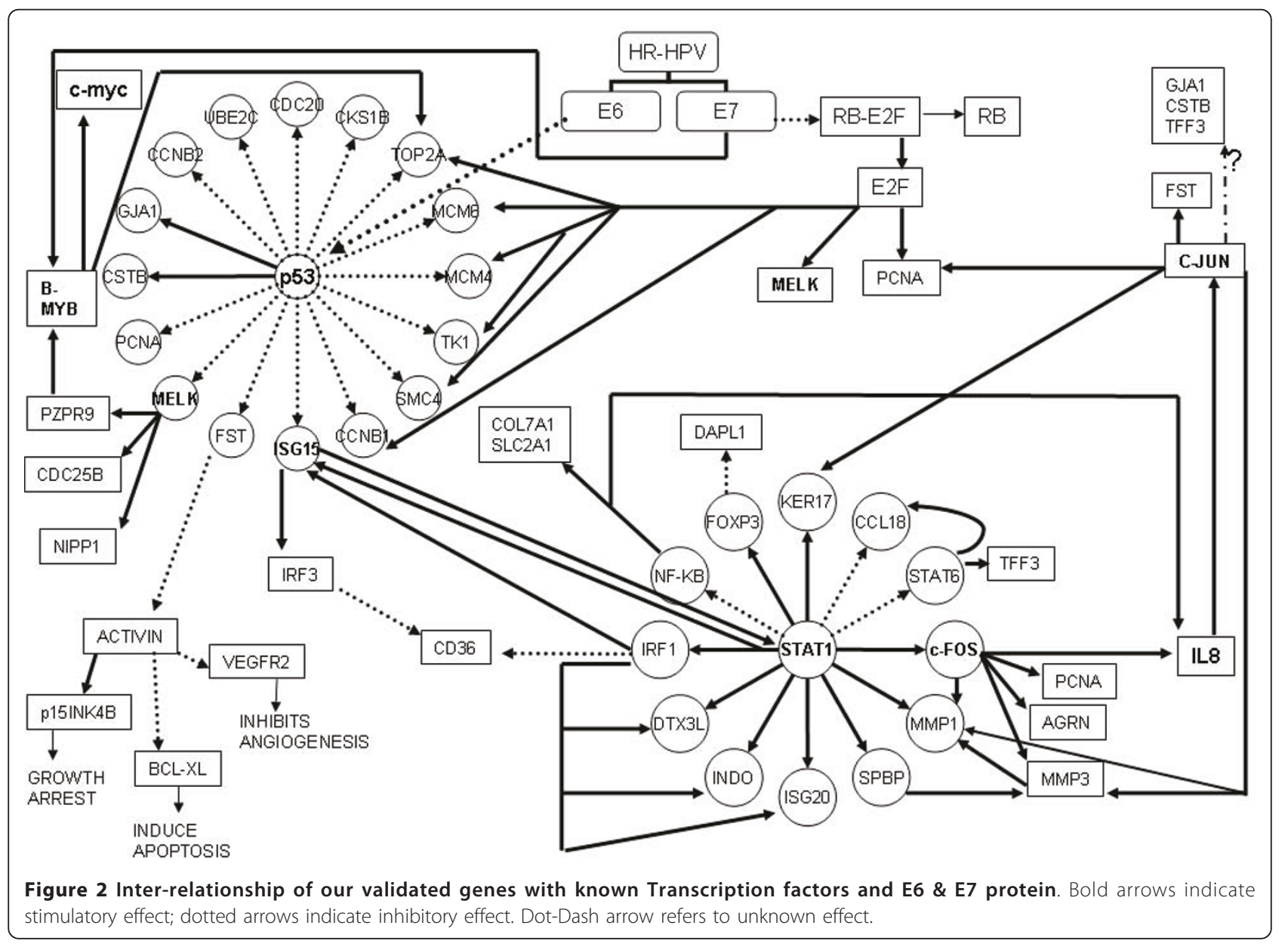




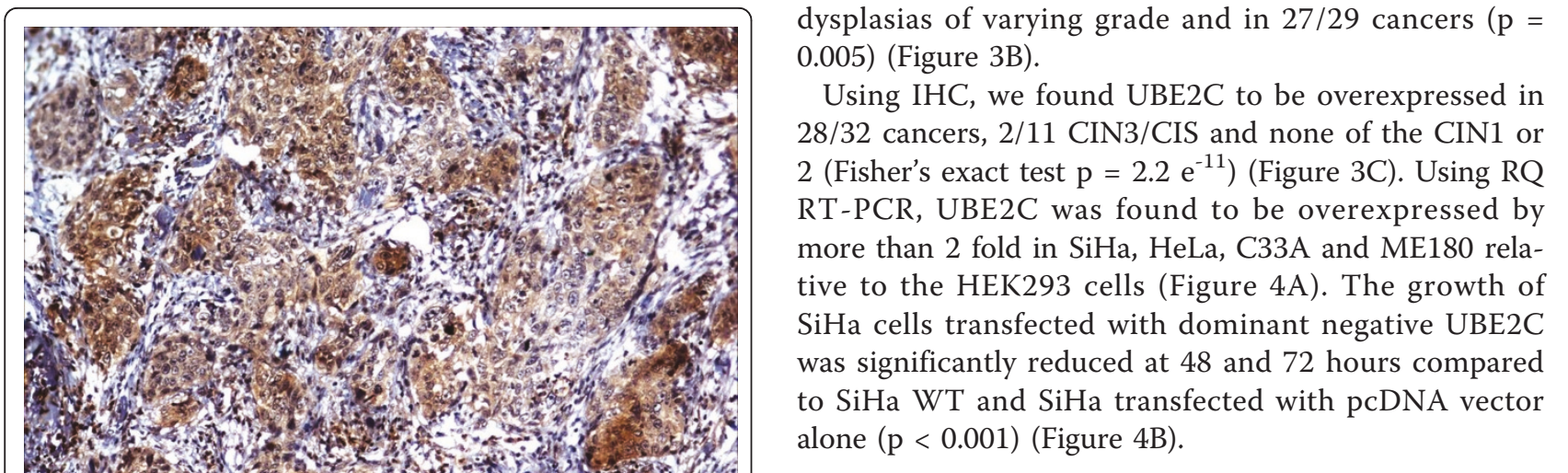

\section{Discussion}

There was good overall concordance between the microarray and the RQ-RT-PCR data. The lower concordance rate seen with the CIN3/CIS may be due to the additional CIN3 sample processed directly using RQ-RTPCR. The relative quantitation values with and without the additional sample is given as Additional File 5. The concordance rate between microarray and semi-quantitative RT-PCR in the study by Gius et al [8] was less than $50 \%$, using the standard microarray data analysis package.

There were several instances, wherein, a small difference in Microarray (above the 2 fold mandatory criteria) sometimes translated to large differences with RQ-RTPCR (e.g. p16, MMP1, MMP3) and vice versa (e.g. CD36). This reinforces the point about the limitation of the microarray technique and it does emphasize the need for further validation, using assays like RQ-RT-PCR.

HPV16 was the predominant subtype seen in the invasive cancers and CIN3/CIS. However, we did not look for all the high risk subtypes and hence cannot exclude multiple subtype infection. Four of the cancers were HPV positive but HPV16 and 18 negative, suggesting that other high risk subtypes could be involved. None of the normal cervical tissues were HPV positive.

The genes that were for the first time, found to be over-expressed in cervical cancers compared to Normal cervix, is given along with information in which other cancers they have been reported to be overexpressed (Table 2A). Our study, for the first time, has identified 20 genes to be up-regulated in cervical cancers and 5 in CIN3; 14 genes were found to be down-regulated. In addition, 26 genes identified by other studies, as to playing a role in cervical cancer, were also confirmed in our study. UBE2C, CCNB1, CCNB2, PLOD2, NUP210, MELK, CDC20 were overexpressed in tumours and in CIN3/CIS relative to both Normal and CIN1/CIN2, suggesting that they could have an important role to play in the early phase of tumorigenesis. Among the genes which were up-regulated in cancers compared to that of whose tumours had been treated only with radical radiotherapy and had been followed up for a minimum period of 3 years, over-expression was seen in a greater number of tumours that failed treatment (6/9) compared to those free of disease at 3 years $(2 / 12)$ ( $\mathrm{p}=$ 0.03). p16 was found to be overexpressed in 19 of 31 


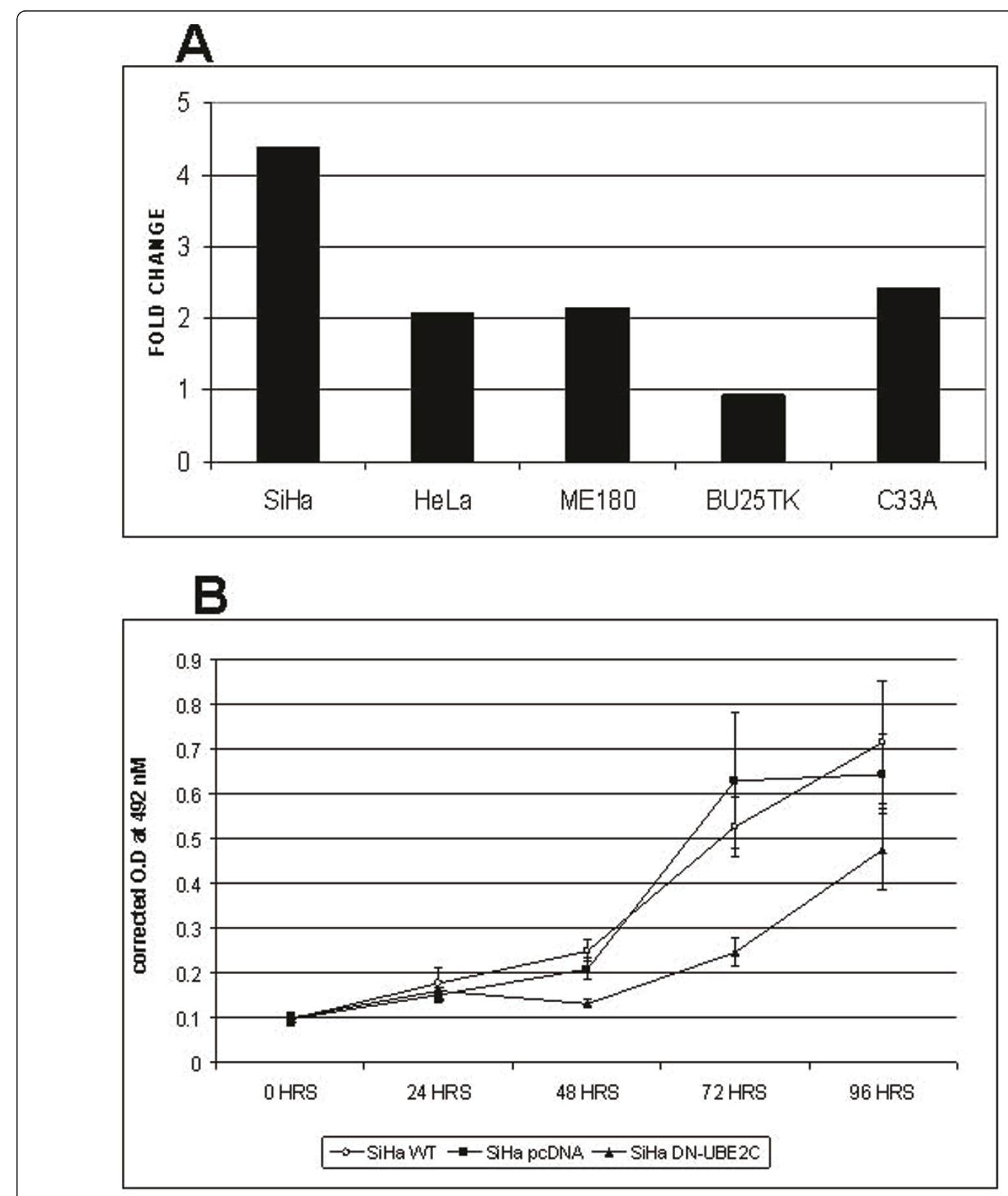

Figure 4 UBE2C experiment data. 4A: RQ of UBE2C in cervical cancer cell lines. Fold change relative to HEK293 cells. 4B: Growth curve for SiHa WT cells, SiHa cells transfected either with pcDNA alone or with Dominant negative UBE2C. $\star$ Denotes a statistically significant change $(p<0.001)$.

Normal, CIN1/2 or CIN3/CIS, IL8, INDO, ISG15, ISG20, AGRN, DTXL, MMP1, MMP3, CCL18, TOP2A AND STAT1 are likely to play an important role in the progression of the disease.

STAT1 gene has a bi-phasic level, a rise in CIN1/2, drop in CIN3/CIS and a significant rise in invasive cancers. STAT1 has been considered generally to be a tumour suppressor, while STAT3 and STAT5 are known to be proto-oncogenes. However, recent studies have shown STAT3 to have both oncogenic and tumour suppressor function [22]. It could be that in cervical cancer, STAT1 may be protective in the early phase of 
HPV infection but could function as a proto-oncogene in the invasive stages of the disease. Highly invasive melanoma cell lines had high levels of STAT1 and c-myc [23].

The study by Lessnick et al., [24] showed that introduction of the potentially oncogenic EWS-FLI transcript into the fibroblasts, resulted in growth arrest rather than transformation. Knocking out p53 using HPV E6 helped overcome the growth arrest but was not sufficient to induce malignant transformation. The study used microarray to identify genes differentially expressed between the EWS-FLI transfected and the mock transfected cell line and found several genes related to growth promotion down-regulated. Our study had several genes [19] overlapping with theirs. Thirteen genes from our study were found to be HPV E6/E7 related genes[20] and 40 of the genes in our list were found to be potential p53 Family Target genes[21] (Additional File 3). In addition, there were 12 myc regulated genes, (MYC Cancer database at http://www.myc-cancer-gene.org/) of which CSTB which has been reported to be down-regulated by myc, was down-regulated in CIN3/CIS and in Cancer [19].

p16 gene, a tumour suppressor has been reported to be over-expressed in dysplasias and invasive cancer of the cervix. Several studies have tried to use this as a marker in the PAP smears for more reliable interpretation of the smear. von Knebel's group from Germany [25], had developed an ELISA to detect p16 in the cervical cell lysates, and reported a $96 \%$ sensitivity to pick up high grade dysplasias. Subsequently, the p16 ELISA assay was compared with Hybrid Capture 2 and was found to have comparable sensitivity and a slightly better specificity (46.9\% versus 35.4\%) [26]. Our RQ-RT-PCR data shows a gross over-expression of p16 in the CIN3 and invasive cancers ( $>250$ fold). In our series of dysplasias and cancers, p16 protein was found to be overexpressed in invasive cancers compared to the dysplasias.

Figure 2 shows the inter-relationship of our genes with E6 and E7 protein and other known Transcription factors including p53, E2F, c-myc, B-MYB and c-Jun. The important genes in our list MELK, ISG15, STAT1, IL8, MMP1 and MMP3, could be playing critical roles in the tumorigenic pathway and could be potential targets for newer therapies.

$\mathrm{UBE} 2 \mathrm{C}$ is an E2 enzyme involved in the process of ubiquitination. Townsley et al. [17] had developed a dominant negative UBE2C which lacks the catalytic activity. When the dominant negative UBE2C was expressed in $\mathrm{SiHa}$ cells, which have nearly 4 fold greater levels of UBE2C compared to HEK293 cells, it produced a significant growth inhibition (Figure 4B), indicating that the dominant negative UBE2C is competing with the wild type UBE2C, and can interfere with cell proliferation. Additional studies will be required to understand the mechanism by which this effect occurs.

\section{Conclusion}

Our study has helped identify newer genes which could play a role in the cervical tumorigenesis and could offer the potential of developing newer diagnostic markers and therapeutic targets. We have confirmed overexpression of MMP3, UBE2C and p16 in tumours, by IHC. This will need to be validated further in a larger series of tumours and dysplasias. UBE2C will need to be studied further to assess its potential as a target for the treatment of cervical cancer.

\section{Additional material}

Additional file 1: List of genes differentially expressed identified by
microarray analysis.
Additional file 2: List of genes taken up for validation.
Additional file 3: Identified genes linked to specific pathways.
Additional file 4: p53 family regulated genes.
Additional file 5: Relative Quantitation with and without CXM180.

\section{Acknowledgements}

This study was funded by the Dept. of Science and Technology, Govt. of India. We would like to acknowledge the help of Ms. Lavanya in the collection and processing of tumour samples. We would also like to thank Dr. Alpana Razdan and Dr. Mainak Majumder of Lablndia Instruments Pvt Ltd laboratory, New Delhi for help with the TLDA assay. We do not have any conflict of interest to declare.

\section{Author details}

${ }^{1}$ Dept. of Molecular Oncology, Cancer Institute (WIA), Chennai, India. ${ }^{2}$ Dept. of Pathology, Cancer Institute (WIA), Chennai, India. ${ }^{3}$ Dept. of Radiation Oncology, Cancer Institute (WIA), Chennai, India.

\section{Authors' contributions}

TR conceived the study; acquired, analysed \& interpreted the data and drafted and revised the article. KS was involved in the acquisition and analysis of the microarray data. NV standardized and together with MB performed the microarray experiments and the immunohistochemistry. SS carried out all the pathological studies and assessment of samples for the microarray studies. GG standardized the UBE2C transfection into the SiHa cells and studied the effect on the growth of the cells. GS was involved in the clinical management and data analysis and follow-up of the patients. All the authors read and approved the final version of the manuscript.

\section{Conflicts of interests}

The authors declare that they have no competing interests.

Received: 9 July 2010 Accepted: 22 February 2011 Published: 22 February 2011

\section{References}

1. Parkin DM, Bray F, Ferlay J, Pisani P: Global cancer statistics:2002. CA Cancer J Clin 2005, 55:74-108.

2. zur Hausen H: Papillomaviruses causing cancer: Evasion from host-cell control in early events in carcinogenesis. J Natl Cancer Inst 2000, 92:690-8.

3. Arends MJ, Buckley CH, Wells M: Aetiology, pathogenesis, and pathology of cervical Neoplasia. J Clin Pathol 1998, 51:96-103. 
4. Schena M, Shalon D, Davis RW, Brown PO: Quantitative monitoring of gene expression patterns with a complementary DNA microarray. Science 1995, 270:467-70.

5. Shim C, Zhang W, Rhee $\mathrm{CH}$, Lee JH: Profiling of differentially expressed genes in human primary cervical cancer by complementary DNA expression array. Clin Cancer Res 1998, 4:3045-50.

6. Song JY, Lee JK, Lee NW, Jung HH, Kim SH, Lee KW: Microarray analysis of normal cervix, carcinoma in situ and invasive cervical cancer: identification of candidate genes in pathogenesis of invasion in cervical cancer. Int J Gynecol Cancer 2008, 18:1051-9.

7. Chen Yan, Miller Christine, Mosher Rebecca, Zhao Xumei, Deeds Jim, Morrissey Mike, Bryant Barb, Yang David, Meyer Ron, Cronin Frank, Gostout SBobbie, Smith-McCune Karen, Schlegel Robert: Identification of cervical cancer markers by Cdna and tissue microarrays. Cancer Res 2003, 63:1927-35.

8. Gius D, Funk MC, Chuang EY, Feng S, Huettner PC, Nguyen L, Bradbury CM, Mishra M, Gao S, Buttin BM, Cohn DE, Powell MA, et al: Profiling microdissected epithelium and stroma to model genomic signatures for cervical carcinogenesis accommodating for covariates. Cancer Res 2007, 67:7113-23.

9. de Roda Husman AM, Walboomers JM, van den Brule AJ, Meijer CJ, Snijders PJ: The use of general primers GP5 and GP6 elongated at their $3^{\prime}$ ends with adjacent highly conserved sequences improves human papillomavirus detection by PCR. J Gen Virol 1995, 76:1057-62.

10. Sotlar K, Diemer D, Dethleffs A, Hack Y, Stubner A, Vollmer N, Menton S, Menton M, Dietz K, Wallwiener D, Kandolf R, Bültmann B: Detection and typing of Human papillomavirus by E6 Nested Multiplex PCR. J Clin Microbiol 2004, 42:3176-84.

11. BRB-Array Tools version 3.7.0 Patch_1 developed by Dr. Richard Simon and Amy Peng Lam.

12. Tusher V, Tibshirani R, Chu G: Significance analysis of microarrays applied to transcriptional responses to ionizing radiation. Proc Natl Acad Sci USA 2001, 98:5116-21.

13. Wright $\mathrm{GW}$, Simon R: A random variance model for detection of differential gene expression in small microarray experiments. Bioinformatics 2003, 19:2448-55.

14. Simon R, Radmacher MD, Dobbin K, McShane LM: Pitfalls in the analysis of DNA microarray data: Class prediction methods. J Natl Cancer Inst 2003, 95:14-8.

15. Rajkumar T, Sharmila R, Majhi U, Selvaluxmi G, Vasanthan A, Shanta V: Bcl-2 and $\mathrm{p} 53$ expression in stage IIB and IIIB cervical cancers. Eur J Gynecol Oncol 1998, 19:556-560.

16. Vijayalakshmi N, Selvaluxmi G, Majhi U, Rajkumar T: Alterations found in $\mathrm{p} 16 / \mathrm{RB} / \mathrm{Cyclin} \mathrm{D} 1$ pathway in the dysplastic and malignant cervical epithelium. Oncol Res 2007, 16:527-533.

17. Townsley FM, Aristarkhov A, Beck S, Hershko A, Ruderman JV: Dominantnegative cyclin-selective ubiquitin carrier protein $\mathrm{E} 2-\mathrm{C} / \mathrm{UbcH} 10$ blocks cells in metaphase. Proc Natl Acad Sci USA 1997, 94:2362-7.

18. Al-Shahrour F, Minguez P, Tárraga J, Montaner D, Alloza E, Vaquerizas JM, Conde L, Blaschke C, Vera J, Dopazo J: BABELOMICS: a systems biology perspective in the functional annotation of genome-scale experiments. Nucleic Acids Research 2006, 34:W472-76.

19. Zeller Kl, Jegga AG, Aronow BJ, O'Donnell KA, Dang CV: An integrated database of genes responsive to the Myc oncogenic transcription factor: identification of direct genomic targets. Genome Biol 2003, 4(10):R69

20. Rosty C, Sheffer M, Tsafrir D, Stransky N, Tsafrir I, Peter M, de Crémoux P, de La Rochefordière A, Salmon R, Dorval T, Thiery JP, Couturier J, Radvanyi F, Domany E, Sastre-Garau X: Identification of a proliferation gene cluster associated with HPV E6/E7 expression level and viral DNA load in invasive cervical carcinoma. Oncogene 2005, 24:7094-104.

21. Sbisà E, Catalano D, Grillo G, Licciulli F, Turi A, Liuni S, Pesole G, De Grassi A Caratozzolo MF, D'Erchia AM, Navarro B, Tullo A, Saccone C, Gisel A: p53Fam TaG: a database resource of human p53, p63 and p73 direct target genes combining in silico prediction and microarray data. BMC Bioinformatics 2007, 8(suppl 1):S20.

22. Ecker A, Simma O, Hoelbl A, Kenner L, Beug H, Moriggl R, Sexl V: The dark and bright side of STAT3: proto-oncogene and tumor suppressor. Front Biosci 2009, 14:2944-58.

23. Gütgemann A, Golob M, Müller S, Buettner R, Bosserhoff AK: Isolation of invasion-associated cDNAs in melanoma. Arch Dermatol Res 2001, 293:283-90.
24. Lessnick SL, Dacwag CS, Golub TR: The Ewing's sarcoma oncoprotein EWS/FLI induces a p53-dependent growth arrest in primary human fibroblasts. Cancer Cell 2002, 1:393-401.

25. Wentzensen N, Hampl M, Herkert M, Reichert A, Trunk MJ, Poremba C, Ridder R, von Knebel Doeberitz M: Identification of high grade cervical dysplasia by the detection of p16INK4a in cell lysates obtained from cervical samples. Cancer 2006, 107:2307-13.

26. Mao C, Balasubramanian A, Yu M, Kiviat N, Ridder R, Reichert A, Herkert M, von Knebel Doeberitz M, Koutsky LA: Evaluation of a new p16(INK4A) ELISA test and a HPV DNA test for cervical cancer screening results from proof of concept study. Int I Cancer 2007, 120:2435-8.

27. Tátrai $P$, Dudás J, Batmunkh E, Máthé M, Zalatnai A, Schaff Z, Ramadori $G$, Kovalszky I: Agrin, a novel basement membrane component in human and rat liver, accumulates in cirrhosis and hepatocellular carcinoma. Lab Invest 2006, 86:1149-60.

28. Fernebro J, Francis $\mathrm{P}$, Edén P, Borg A, Panagopoulos I, Mertens F, VallonChristersson J, Akerman M, Rydholm A, Bauer HC, Mandahl N, Nilbert M: Gene expression profiles relate to SS18/SSX fusion type in synovial sarcoma. Int J Cancer 2006, 118:1165-72.

29. Leung SY, Yuen ST, Chu KM, Mathy JA, Li R, Chan AS, Law S, Wong J, Chen X, So S: Expression profiling identifies chemokine (C-C motif) ligand 18 as an independent prognostic indicator in gastric cancer. Gastroenterology 2004, 127:457-69.

30. Slotky M, Shapira M, Ben-Izhak O, Linn S, Futerman B, Tsalic M, Hershko DD: The expression of the ubiquitin ligase subunit Cks1 in human breast cancer. Breast Cancer Res 2005, 7:737-44.

31. Kita Y, Mimori K, Tanaka F, Matsumoto T, Haraguchi N, Ishikawa K, Matsuzaki S, Fukuyoshi Y, Inoue H, Natsugoe S, Aikou T, Mori M: Clinical significance of LAMB3 and COL7A1 mRNA in esophageal squamous cell carcinoma. Eur I Surg Oncol 2009, 35:52-8.

32. Rayala SK, den Hollander P, Balasenthil S, Yang Z, Broaddus RR, Kumar R: Functional regulation of oestrogen receptor pathway by the dynein light chain 1. EMBO Rep 2005, 6:538-44.

33. Weinstein EJ, Bourner M, Head R, Zakeri H, Bauer C, Mazzarella R: URP1: a member of a novel family of PH and FERM domain-containing membrane-associated proteins is significantly over-expressed in lung and colon carcinomas. Biochem Biophys Acta 2003, 1637:207-16.

34. Li CM, Kim CE, Margolin AA, Guo M, Zhu J, Mason JM, Hensle TW, Murty W, Grundy PE, Fearon ER, D'Agati V, Licht JD, Tycko B: CTNNB1 mutations and overexpression of Wnt/beta-catenin target genes in WT1-mutant Wilms' tumors. Am J Pathol 2004, 165:1943-53.

35. Hammer NA, Hansen TO, Byskov AG, Rajpert-De Meyts E, Grøndahl ML, Bredkjaer HE, Wewer UM, Christiansen J, Nielsen FC: Expression of IGF-II mRNA-binding proteins (IMPs) in gonads and testicular cancer. Reproduction 2005, 130:203-212.

36. Himoto T, Kuriyama S, Zhang JY, Chan EK, Nishioka M, Tan EM: Significance of autoantibodies against insulin-like growth factor II mRNA-binding proteins in patients with hepatocellular carcinoma. Int J Oncol 2005, 26:311-7.

37. Santegoets LA, van Seters M, Heijmans-Antonissen C, Kleinjan A, van Beurden M, Ewing PC, Kühne LC, Beckmann I, Burger CW, Helmerhorst TJ, Blok LJ: Reduced local immunity in HPV-related VIN: expression of chemokines and involvement of immunocompetent cells. Int J Cancer 2008, 123:616-22.

38. Shinoda Y, Kozaki K, Imoto I, Obara W, Tsuda H, Mizutani Y, Shuin T, Fujioka T, Miki T, Inazawa J: Association of KLK5 overexpression with invasiveness of urinary bladder carcinoma cells. Cancer Sci 2007, 98:1078-86.

39. Yousef GM, Scorilas A, Nakamura T, Ellatif MA, Ponzone R, Biglia N, Maggiorotto F, Roagna R, Sismondi P, Diamandis EP: The prognostic value of the human kallikrein gene 9 (KLK9) in breast cancer. Breast Cancer Res Treat 2003, 78:149-58.

40. Gray D, Jubb AM, Hogue D, Dowd P, Kljavin N, Yi S, Bai W, Frantz G, Zhang Z, Koeppen H, de Sauvage FJ, Davis DP: Maternal embryonic leucine zipper kinase/murine protein serine-threonine kinase 38 is a promising therapeutic target for multiple cancers. Cancer Res 2005, 65:9751-61.

41. Marie SK, Okamoto OK, Uno M, Hasegawa AP, Oba-Shinjo SM, Cohen T, Camargo AA, Kosoy A, Carlotti CG Jr, Toledo S, Moreira-Filho CA, Zago MA, Simpson AJ, Caballero OL: Maternal embryonic leucine zipper kinase transcript abundance correlates with malignancy grade in astrocytomas. Int J Cancer 2008, 122:807-15. 
42. Dong $\mathrm{S}$, Nutt $\mathrm{CL}$, Betensky RA, Stemmer-Rachamimov AO, Denko NC, Ligon $\mathrm{KL}$, Rowitch DH, Louis DN: Histology based expression profiling yields novel prognostic markers in human glioblastoma. $J$ Neuropathol Exp Neurol 2005, 64:948-55.

43. Ikeda M, Hirabayashi S, Fujiwara N, Mori H, Kawata A, lida J, Bao Y, Sato Y, lida T, Sugimura H, Hata Y: Ras-association domain family protein 6 induces apoptosis via both caspase-dependent and caspaseindependent pathways. Exp Cell Res 2007, 313:1484-95.

44. Fang J, Quinones QJ, Holman TL, Morowitz MJ, Wang Q, Zhao H, Sivo F, Maris JM, Wahl ML: The H+-linked monocarboxylate transporter (MCT1/ SLC16A1): a potential therapeutic target for high-risk neuroblastoma. Mol Pharmacol 2006, 70:2108-15.

45. Kulawiec M, Safina A, Desouki MM, Still I, Matsui S, Bakin A, Singh KK: Tumorigenic transformation of human breast epithelial cells induced by mitochondrial DNA depletion. Cancer Biol Ther 2008, 7.

46. Stav D, Bar I, Sandbank J: Usefulness of CDK5RAP3, CCNB2, and RAGE genes for the diagnosis of lung adenocarcinoma. Int J Biol Markers 2007, 22:108-13

47. De Martino I, Visone R, Wierinckx A, Palmieri D, Ferraro A, Cappabianca P, Chiappetta G, Forzati F, Lombardi G, Colao A, Trouillas J, Fedele M, Fusco A: HMGA proteins up-regulate CCNB2 gene in mouse and human pituitary adenomas. Cancer Res 2009, 69:1844-50.

48. Villalva C, Trempat P, Greenland C, Thomas C, Girard JP, Moebius F, Delsol G, Brousset P: Isolation of differentially expressed genes in NPMALK-positive anaplastic large cell lymphoma. Br J Haematol 2002, 118:791-8.

49. Ryu B, Kim DS, Deluca AM, Alani RM: Comprehensive expression profiling of tumor cell lines identifies molecular signatures of melanoma progression. PLoS One 2007, 2:e594.

50. Méhul B, Bernard D, Brouard M, Delattre C, Schmidt R: Influence of calcium on the proteolytic degradation of the calmodulin-like skin protein (calmodulin-like protein 5) in psoriatic epidermis. Exp Dermatol 2006, 15:469-77

51. Zhang B, Nie X, Xiao B, Xiang J, Shen S, Gong J, Zhou M, Zhu S, Zhou J, Qian J, Lu H, He X, Li X, Hu G, Li G: Identification of tissue-specific genes in nasopharyngeal epithelial tissue and differentially expressed genes in nasopharyngeal carcinoma by suppression subtractive hybridization and cDNA microarray. Genes Chromosomes Cancer 2003, 38:80-90.

52. Imai FL, Uzawa K, Nimura Y, Moriya T, Imai MA, Shiiba M, Bukawa H, Yokoe $\mathrm{H}$, Tanzawa $\mathrm{H}$ : Chromosome 1 open reading frame 10 (C1orf10) gene is frequently down-regulated and inhibits cell proliferation in oral squamous cell carcinoma. Int J Biochem Cell Biol 2005, 37:1641-55.

53. Colombo J, Fachel AA, De Freitas Calmon M, Cury PM, Fukuyama EE, Tajara EH, Cordeiro JA, Verjovski-Almeida S, Reis EM, Rahal P: Gene expression profiling reveals molecular marker candidates of laryngeal squamous cell carcinoma. Oncol Rep 2009, 21:649-63.

54. Alho $\mathrm{H}$, Kolmer M, Harjuntausta $T$, Helén P: Increased expression of diazepam binding inhibitor in human brain tumors. Cell Growth Differ 1995, 6:309-14

55. Gazi MH, He M, Cheville JC, Young CY: Downregulation of IgG Fc binding protein (Fc gammaBP) in prostate cancer. Cancer Biol Ther 2008, 7:70-5.

56. Asanoma $\mathrm{K}$, Kato $\mathrm{H}$, Inoue $\mathrm{T}$, Matsuda $\mathrm{T}$, Wake $\mathrm{N}$ : Analysis of a candidate gene associated with growth suppression of choriocarcinoma and differentiation of trophoblasts. J Reprod Med 2004, 49:617-26.

57. Chen Y, Petersen S, Pacyna-Gengelbach M, Pietas A, Petersen I: Identification of a novel homeobox-containing gene, LAGY, which is down-regulated in lung cancer. Oncology 2003, 64:450-458.

58. Masood R, McGarvey ME, Zheng T, Cai J, Arora N, Smith DL, Sloane N, Gill PS: Antineoplastic urinary protein inhibits Kaposi's sarcoma and angiogenesis in vitro and in vivo. Blood 1999, 93:1038-44

59. Ye H, Yu T, Temam S, Ziober BL, Wang J, Schwartz JL, Mao L, Wong DT, Zhou $X$ : Transcriptomic dissection of tongue squamous cell carcinoma. BMC Genomics 2008, 9:69.

60. John R, El-Rouby NM, Tomasetto C, Rio MC, Karam SM: Expression of TFF3 during multistep colon carcinogenesis. Histol Histopathol 2007, 22:743-51.

61. Takano T, Yamada H: Trefoil factor 3 (TFF3): a promising indicator for diagnosing thyroid follicular carcinoma. Endocr J 2009, 56:9-16.

62. Zhao M, Kim YT, Yoon BS, Kim SW, Kang MH, Kim SH, Kim JH, Kim JW, Park YW: Expression profiling of cyclin B1 and D1 in cervical carcinoma. Exp Oncol 2006, 28:44-8.
63. Bellanger S, Blachon S, Mechali F, Bonne-Andrea C, Thierry F: High-risk but not low-risk HPV E2 proteins bind to the APC activators Cdh1 and Cdc20 and cause genomic instability. Cell Cycle 2005, 4:1608-15.

64. Chan DW, Yu SY, Chiu PM, Yao KM, Liu VW, Cheung AN, Ngan HY: Over-expression of FOXM1 transcription factor is associated with cervical cancer progression and pathogenesis. J Pathol 2008, 215:245-52.

65. de Boer CJ, van Dorst E, van Krieken H, Jansen-van Rhijn CM, Warnaar SO, Fleuren GJ, Litvinov SV: Changing Roles of Cadherins and Catenins during Progression of Squamous Intraepithelial Lesions in the Uterine Cervix. Am J Pathol 1999, 55:505-15.

66. Klaes R, Friedrich T, Spitkovsky D, Ridder R, Rudy W, Petry U, DallenbachHellweg G, Schmidt D, von Knebel Doeberitz M: Overexpression of p16INK4a as a specific marker for dysplastic and neoplastic epithelial cells of the cervix uteri. Int J Cancer 2001, 92:276-284.

67. Wong YF, Cheung TH, Tsao GS, Lo KW, Yim SF, Wang WW, Heung MM, Chan SC, Chan LK, Ho TW, Wong KW, Li C, Guo Y, Chung TK, Smith DI: Genome-wide gene expression profiling of cervical cancer in Hong Kong women by oligonucleotide microarray. Int J Cancer 2006, 18:2461-9.

68. Wilting SM, de Wilde J, Meijer CJ, Berkhof J, Yi Y, van Wieringen WN, Braakhuis BJ, Meijer GA, Ylstra B, Snijders PJ, Steenbergen RD: Integrated genomic and transcriptional profiling identifies chromosomal loci with altered gene expression in cervical cancer. Genes Chromosomes Cancer 2008, 47:890-905

69. Kobayashi A, Weinberg V, Darragh T, Smith-McCune K: Evolving immunosuppressive microenvironment during human cervical carcinogenesis. Mucosal Immunol 2008, 1:412-20.

70. Sgarlato GD, Eastman $\mathrm{CL}$, Sussman $\mathrm{HH}$ : Panel of genes transcriptionally up-regulated in squamous cell carcinoma of the cervix identified by representational difference analysis, confirmed by macroarray, and validated by real-time quantitative reverse transcription-PCR. Clin Chem 2005, 51:27-34.

71. Nees M, Geoghegan JM, Hyman T, Frank S, Miller L, Woodworth CD: Papillomavirus type 16 oncogenes downregulate expression of interferon-responsive genes and upregulate proliferation-associated and NF-kappaB-responsive genes in cervical keratinocytes. J Virol 2001, 75:4283-96.

72. Maddox P, Sasieni P, Szarewski A, Anderson M, Hanby A: Differential expression of keratins 10,17, and 19 in normal cervical epithelium, cervical intraepithelial neoplasia, and cervical carcinoma. J Clin Pathol 1999, 52:41-6.

73. Martinez I, Gardiner AS, Board KF, Monzon FA, Edwards RP, Khan SA: Human papillomavirus type 16 reduces the expression of microRNA-218 in cervical carcinoma cells. Oncogene 2008, 27:2575-82.

74. Ishimi Y, Okayasu I, Kato C, Kwon HJ, Kimura H, Yamada K, Song SY: Enhanced expression of $\mathrm{Mcm}$ proteins in cancer cells derived from uterine cervix. Eur J Biochem 2003, 270:1089-101.

75. Chen Y, Miller C, Mosher R, Zhao X, Deeds J, Morrissey M, Bryant B, Yang D, Meyer R, Cronin F, Gostout BS, Smith-McCune K, Schlegel R: Identification of cervical cancer markers by Cdna and tissue microarrays. Cancer Res 2003, 63:1927-35

76. Narayan G, Bourdon V, Chaganti S, Arias-Pulido H, Nandula SV, Rao PH, Gissmann L, Dürst M, Schneider A, Pothuri B, Mansukhani M, Basso K, Chaganti RS, Murty W: Gene dosage alterations revealed by CDNA microarray analysis in cervical cancer: identification of candidate amplified and overexpressed genes. Genes Chromosomes Cancer 2007, 46:373-84

77. Hagemann T, Bozanovic T, Hooper S, Ljubic A, Slettenaar VI, Wilson JL, Singh N, Gayther SA, Shepherd JH, Van Trappen PO: Molecular profiling of cervical cancer progression. Br J Cancer 2007, 96:321-8.

78. Gius D, Funk MC, Chuang EY, Feng S, Huettner PC, Nguyen L, Bradbury CM, Mishra M, Gao S, Buttin BM, Cohn DE, Powell MA, Horowitz NS, Whitcomb BP, Rader JS: Profiling microdissected epithelium and stroma to model genomic signatures for cervical carcinogenesis accommodating for covariates. Cancer Res 2007, 67:7113-23.

79. Lee WY, Huang SC, Hsu KF, Tzeng CC, Shen WL: Roles for hypoxia related genes during cervical carcinogenesis: somatic evolution during the hypoxia-glycolysis-acidosis sequence. Gynecol Oncol 2008, 108:377-84.

80. Hudelist G, Czerwenka K, Singer C, Pischinger K, Kubista E, Manavi M: cDNA array analysis of cytobrush-collected normal and malignant cervical epithelial cells: a feasibility study. Cancer Genet Cytogenet 2005, 158:35-42. 
81. Fujiwaki R, Hata K, Moriyama M, Iwanari O, Katabuchi H, Okamura $\mathrm{H}$, Miyazaki K: Clinical value of thymidine kinase in patients with cervical carcinoma. Oncology 2001, 61:47-54.

82. Santin AD, Zhan F, Bignotti E, Siegel ER, Cané S, Bellone S, Palmieri M, Anfossi S, Thomas M, Burnett A, Kay HH, Roman JJ, O'Brien TJ, Tian E, Cannon MJ, Shaughnessy J Jr, Pecorelli S: Gene expression profiles of primary HPV16- and HPV18-infected early stage cervical cancers and normal cervical epithelium: identification of novel candidate molecular markers for cervical cancer diagnosis and therapy. Virology 2005, 331:269-91.

83. Branca M, Ciotti M, Giorgi C, Santini D, Di Bonito L, Costa S, Benedetto A, Bonifacio D, Di Bonito P, Paba P, Accardi L, Syrjänen S, Favalli C, Syrjänen K, HPV-PathogenISS Study Group: Up-regulation of proliferating cell nuclear antigen (PCNA) is closely associated with high-risk human papillomavirus (HPV) and progression of cervical intraepithelial neoplasia (CIN), but does not predict disease outcome in cervical cancer. Eur J Obstet Gynecol Reprod Biol 2007, 130:223-3.

84. Du M, Fan X, Hong E, Chen JJ: Interaction of oncogenic papillomavirus E6 proteins with fibulin-1. Biochem Biophys Res Commun 2002, 296:962-9.

85. Coleman N, Stanley MA: Expression of the myelomonocytic antigens CD36 and L1 by keratinocytes in squamous intraepithelial lesions of the cervix. Hum Pathol 1994, 25:73-9.

86. Frederick MJ, Henderson Y, Xu X, Deavers MT, Sahin AA, Wu H, Lewis DE, El-Naggar AK, Clayman GL: In vivo expression of the novel CXC chemokine BRAK in normal and cancerous human tissue. Am J Pathol 2000, 156:1937-50.

87. Cao YW, Lu TC, Pan XL, Li F, Zhong HH, Sun Y, Jiang JF, Li L: Correlation of expression of connexion to growth and progression of cervical carcinoma in situ. Ai Zheng 2005, 24:567-72.

\section{Pre-publication history}

The pre-publication history for this paper can be accessed here: http://www.biomedcentral.com/1471-2407/11/80/prepub

\section{Submit your next manuscript to BioMed Central and take full advantage of:}

- Convenient online submission

- Thorough peer review

- No space constraints or color figure charges

- Immediate publication on acceptance

- Inclusion in PubMed, CAS, Scopus and Google Scholar

- Research which is freely available for redistribution

Submit your manuscript at www.biomedcentral.com/submit
C Biomed Central 